This work is licensed under a Creative Commons Attribution License (CC BY 4.0).

Research article

urn:1sid:zoobank.org:pub:C4F57584-0AD9-47C9-BA95-02133C434941

\title{
Integrative description of a new Tunisian tardigrade species, Macrobiotus azzunae sp. nov. (Eutardigrada, Macrobiotidae, hufelandi group)
}

\author{
Jamila BEN MARNISSI ${ }^{\circledR}$, Michele CESARI ${ }^{\circledR 2}$, \\ Lorena REBECCHI ${ }^{\circledR 3,{ }^{*}}$ \& Roberto BERTOLANI ${ }^{(1,5}$ \\ ${ }^{1}$ Department of Biological Sciences, Faculty of Mathematical, Physical and Natural Sciences of Tunis, \\ University of Tunis El Manar, 2092 El Manar, Tunis, Tunisia. \\ ${ }^{2,3}$ Department of Life Sciences, University of Modena and Reggio Emilia, \\ Via G. Campi 213/D, 41125, Modena, Italy. \\ ${ }^{4}$ Department of Education and Humanities, University of Modena and Reggio Emilia, \\ Via A. Allegri 9, 42121 Reggio Emilia, Italy. \\ ${ }^{5}$ Museo Civico di Storia Naturale, Lungadige Porta Vittoria, 9, 37129 Verona, Italy. \\ *Corresponding author: lorena.rebecchi@unimore.it \\ ${ }^{1}$ Email: jamila.marnissi@fst.utm.tn \\ 2Email: michele.cesari@unimore.it \\ ${ }^{4}$ Email: roberto.bertolani@unimore.it

\footnotetext{
${ }^{1}$ urn:1sid:zoobank.org:author:F10DD853-D540-4984-A16A-5D5EC377E4C0

${ }^{2}$ urn:lsid:zoobank.org:author:87D45951-C71A-48C1-92A1-C07387A80284

${ }^{3}$ urn:Isid:zoobank.org:author:5A02A091-C92C-44A3-B7C4-672B9D27B590

${ }^{4}$ urn:lsid:zoobank.org:author:A7381EA2-93C7-4127-9460-2640581E48B6
}

\begin{abstract}
In this paper a new tardigrade species, Macrobiotus azzunae sp. nov., from Tunisia, is described. An integrative taxonomic approach was applied by combining morphological, morphometric and molecular data. In particular, light and scanning electron microscopy observations, and four genetic markers, three nuclear (18S rRNA, 28S rRNA and ITS-2) and one mitochondrial (COI) were used. The analysis showed that M. azzunae sp. nov. belongs to the Macrobiotus hufelandi group and is most similar to Macrobiotus sandrae Bertolani \& Rebecchi, 1993. It differs from M. sandrae by a more pronounced constriction of the first macroplacoid (hardly visible in M. sandrae) and for the eggshell shape, with thinner wires of the reticulum and meshes around the processes larger than the inter-process meshes in M. azzunae sp. nov., while all meshes are similar in size in M. sandrae. The species is gonochoristic. With this discovery, there are 33 species of tardigrades identified in Tunisia, all nonmarine. This result, compared with nearby Sicily, where more research has been conducted, indicates that there is a considerable potential for identification of new species. Further research will be most informative if multiple habitats are explored and if carried out with an integrated approach as done in this present work.
\end{abstract}

Keywords. Tardigrada, Ain Soltan Forest, Tunisia, Macrobiotus azzunae, new species. 
Ben Marnissi J., Cesari M., Rebecchi L. \& Bertolani R. 2021. Integrative description of a new Tunisian tardigrade species, Macrobiotus azzunae sp. nov. (Eutardigrada, Macrobiotidae, hufelandi group). European Journal of Taxonomy 758: 122-146. https://doi.org/10.5852/ejt.2021.758.1429

\section{Introduction}

Tardigrades are hygrophilous micrometazoans whose outstanding resistance enables most of them to inhabit a large variety of habitats from the greatest depths of oceans to the highest mountain peaks, as well as extreme environments such as cryoconite holes. In terrestrial environments they colonize mosses, lichens, leaf litter and soil which receive stochastic hydration (Nelson et al. 2015; Schill 2018). Much research on the diversity and distribution of tardigrade fauna has been carried out in recent years in various parts of the world, especially considering the terrestrial environment. This has led to a significant increase in the number of known species: 531 in 1983 (Ramazzotti \& Maucci 1983), about 960 in 2005 (Guidetti \& Bertolani 2005) and more than 1300 species in 2020 (Degma et al. 2020). Nevertheless, knowledge of the diversity and distribution of North African tardigrades is still very limited and in particular in Tunisia, for which only three studies have been conducted. The first report on Tunisian tardigrades comes from a survey by Iharos (1978) in Northern Tunisian regions in which eleven species of tardigrades were detected. Then, Binda \& Pilato (1987) studied the tardigrade fauna of Salambo (Tunis), Tabarka and Ain Drahem (Jendouba), and recently Gąsiorek et al. (2017) studied the tardigrade fauna of Bni Mtir, Jendouba. Currently, the known Tunisian tardigrade fauna includes 32 species, of which one, Bryodelphax maculatus Gąsiorek, Stec, Morek, Marnissi, Michalczyk, 2017, was originally discovered from the same region considered here, namely the Kroumirie Mountains. The Kroumirie Mountains are located in Northern Tunisia near the Algerian boundary and are characterized by a climate which varies from sub-humid to humid in winter. The Kroumirie forests are covered especially by cork oaks (Quercus suber L.) and Algerian oaks (Quercus canariensis Willd.) (Stambouli-Essassi et al. 2007). The analysis of the tardigrade fauna of a moss collected at the Kroumirie Mountains led us to find a new eutardigrade species (Macrobiotus azzunae sp. nov.) belonging to the Macrobiotus hufelandi group, considered as one of the most common groups of limnoterrestrial tardigrades on the planet (McInnes 1994; Kaczmarek \& Michalczyk 2017a; McInnes et al. 2017). In this study we combined classical morphological and morphometric methods with modern molecular techniques in an integrative approach as suggested by Cesari et al. (2009, 2011, 2020), Stec et al. (2018b) and Kayastha et al (2020). Using phase contrast (PhC) light microscopy (LM), differential interference contrast (DIC) and scanning electron microscopy (SEM), we were able to describe the phenotypic characteristics of the new species whereas the amplification of DNA markers (three nuclear, 18S rRNA, 28S rRNA and ITS-2, and one mitochondrial, COI) provided barcodes for the genetic identification of this new species.

\section{Material and methods}

\section{Tardigrade collection}

The moss containing the new species was collected in April 2017 by the first author from Ain Soltan forest in the North West of Tunisia (Fig. 1) on a trunk of an Algerian oak tree. The sample was stored dry in a labeled paper bag and then sent to the Laboratory of Evolutionary Zoology at the Department of Life Sciences, University of Modena and Reggio Emilia (UNIMORE), Italy. In order to extract tardigrades from the sample, a small portion of the collected substrate was placed and maintained in tap water at room temperature $\left(20^{\circ} \mathrm{C}\right)$ for about half an hour. The sample was then sieved to separate tardigrades and their eggs from the substrate, and both animals and eggs were isolated using a glass pipette under a stereo microscope.

\section{Microscopy and imaging}

The collected specimens (eggs and animals) were mounted on slides in Faure-Berlese fluid (permanent slides) or fixed in Carnoy fixative (methanol: acetic acid, 3:1) and in the latter case then stained with a drop of acetic-lactic orcein (Rebecchi \& Bertolani 1988) for LM observations (not permanent slides). 
Observations and measurements of the sclerified parts of animals and eggshells were carried out with $\mathrm{LM}$ under PhC and DIC up to the maximum magnification (100× oil objective) with a Leica DM RB microscope equipped with a Nikon DS-Fi 1 digital camera, at the Department of Life Sciences, UNIMORE. The species was identified by comparing the specimens with the original descriptions of similar species of Macrobiotus (for references see Results: Differential diagnosis) and, when possible, with the original type material of some of those species. In particular, we have examined the following material from Maucci's collection (thanks to the Civic Museum of Natural History of Verona, Italy): slides CT14009 holotype and CT14015 egg of Macrobiotus madegassus Maucci, 1993; slide CT14701 one animal and one egg (paratypes) of Macrobiotus personatus Biserov, 1990; from Bertolani's collection of the Department of Life Sciences, UNIMORE, Italy: slide C460-S97 holotype of Macrobiotus sandrae Bertolani \& Rebecchi, 1993 and for the same species slides from the type locality C442-S79 (Animal) and C450-S01 and C2346-S2 (eggs). These specimens and eggs were analyzed under LM.

Measurements of animal length, claws and buccal-pharyngeal apparatus details were taken according to Pilato (1981). The external buccal tube diameter was measured at the level of the stylet support insertion point. We calculated the $p t$ index which is the percentage ratio between the length of a structure and the length of the buccal tube measured from the medio-dorsal ridge of the buccal armature to the base of the pharyngeal apophyses (Pilato 1981). Single measurements are available in Supp. file 1.

Fifteen additional specimens were prepared for SEM analyses according to Bertolani et al. (2014), and observed with a Philips SEM XL 40, available at the Centro Interdipartimentale Grandi Strumenti (CIGS) of UNIMORE.

\section{Molecular analysis}

Before molecular analysis, each specimen was identified and photographed in vivo with LM using the method described by Cesari et al. (2011) in order to obtain voucher specimens. Supp. file 2 shows the buccal-pharyngeal apparatus of a hologenophore voucher specimen, showing how it is possible to obtain good morphological information on alive animals even when the entire animal has to be used

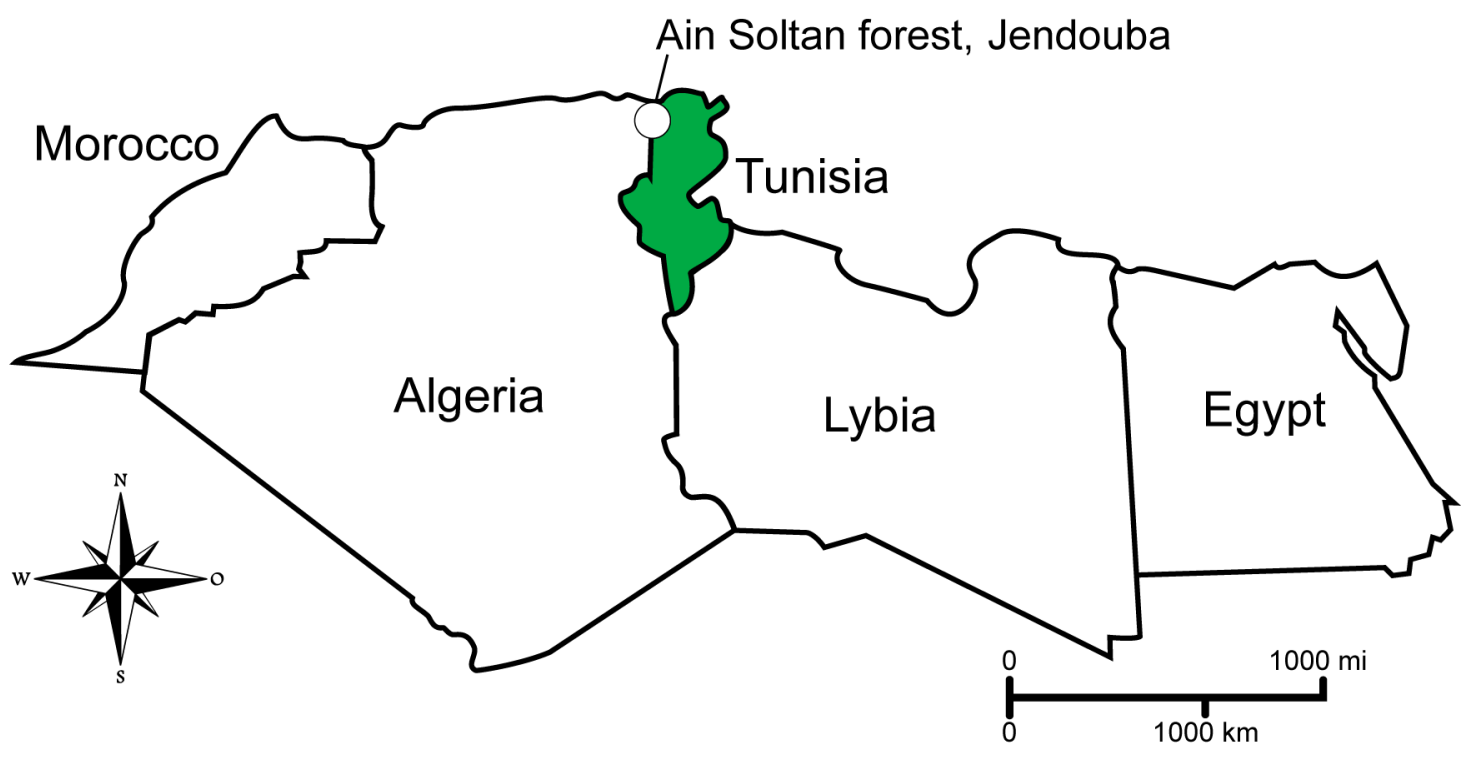

Fig. 1. Map of the sampling locality (circle) in the North-West of Tunisia. 
BEN MARNISSI J. et al., Description of a new Tunisian tardigrade species

Table 1. List of specimens of M. azzunae sp. nov. and M. sandrae Bertolani \& Rebecchi, 1993 utilized for molecular analyses. Abbreviation: N/A = not available. * These specimens were analyzed for the COI gene in Bertolani et al. (2011b).

\begin{tabular}{lllll}
\hline Specimen & $\mathbf{1 8 S}$ & $\mathbf{2 8 S}$ & ITS-2 & COI \\
\hline Macrobiotus azzunae & & & & \\
C4218 V1 & N/A & N/A & N/A & MW698695 \\
C4218 V2 & N/A & N/A & N/A & MW698696 \\
C4218 V4 & MW695447 & MW695450 & MW695454 & MW698697 \\
C4218 T5 & MW695448 & MW695451 & MW695455 & MW698698 \\
C4218 T6 & MW695449 & MW695452 & MW695456 & N/A \\
C4218 V7 & N/A & MW695453 & MW695457 & MW698699 \\
Macrobiotus sandrae & & & & \\
C2945 b & MW695445 & N/A & N/A & HQ876573* \\
C2945 e & MW695446 & N/A & N/A & HQ876577* \\
\hline
\end{tabular}

for molecular analysis. Table 1 lists the specimens utilized. Genomic DNA was extracted from six Tunisian single animals using a rapid salt and ethanol precipitation following the protocol described by Cesari et al. (2009). We amplified four DNA fragments: the small ribosome subunit (18S rRNA), the large ribosome subunit (28S rRNA), the internal transcribed spacer (ITS-2), and the cytochrome oxidase subunit I (COI), using the primers and protocols described by Bertolani et al. (2014), Cesari et al. (2016), Stec et al. (2018d) and Cesari et al. (2009), respectively. Additionally, a portion of the $18 \mathrm{~S}$ gene was sequenced for two additional specimens of $M$. sandrae sampled in the locus typicus of the species (Black Forest, Germany). GenBank accession numbers of obtained sequences are listed in Table 1. The amplified products were gel purified using the Wizard Gel and PCR cleaning (Promega) kit, and fragments were sequenced according to the protocols described in Bertolani et al. (2014). All COI sequences were translated into protein sequences in MEGAX (Kumar et al. 2018) to check for the presence of stop codons, and therefore for the presence of pseudogenes. Sequences of the four genes pertaining to species of the hufelandi group were used for molecular comparisons (Table 2) and aligned with the newly produced sequences using the MAFFT algorithm (Katoh et al. 2002) as implemented in the MAFFT online service (Katoh et al. 2017) and checked by visual inspection (Supp. file 3, Supp. file 4, Supp. file 5, Supp. file 6). Uncorrected pairwise distances were computed using MEGAX (Supp. file 7, Supp. file 8, Supp. file 9, Supp. file 10). Furthermore, relationships between COI haplotypes pertaining to the clade A nested in the M. hufelandi complex sensu Stec et al. (2021) were estimated using a parsimony network, by applying the method described in Templeton et al. (1992), as implemented in TCS ver. 1.21 (Clement et al. 2000) and visualized using tcsBU (Múrias dos Santos et al. 2016). A 95\% connection limit was employed, as it has been suggested as a useful general tool in species assignments and discovery (Hart \& Sunday 2007). Putative species were also inferred by using the Poisson Tree Process (PTP; Zhang et al. 2013) and the Automatic Barcode Gap Discovery method (ABGD; Puillandre et al. 2012). PTP is a coalescent-based species delimitation method that uses non-ultrameric gene trees as input, and utilizes heuristic algorithms to identify speciation events relative to numbers of substitutions. The PTP method produces robust diversity estimates, in some cases more robust than those estimated under the generalized mixed Yule coalescent model (Tang et al. 2014). The starting gene tree was a maximum likelihood (ML) tree computed using RAxML ver. 7.2.4 (Stamatakis 2006), as implemented in CIPRES (Miller et al. 2010), under the GTR $+\mathrm{I}+\mathrm{G}$ model, as inferred by using the Akaike Information Criterion on jModelTest2 (Guindon \& Gascuel 2003; Darriba et al. 2012). A sequence of Mesobiotus hilariae Vecchi, Cesari, Bertolani, Jönsson, Rebecchi \& Guidetti, 2016 (GenBank accession number: KT226108) was used as outgroup. Bootstrap 
resampling with 1000 replicates was undertaken via the rapid bootstrap procedure of Stamatakis et al. (2008) to assign support to branches in the ML tree. In order to consider different evolutionary models for the three COI codons, a Bayesian tree was computed using the following models, as inferred by MrModeltest ver. 2 (Nylander 2004): $\mathrm{SYM}+\mathrm{I}+\mathrm{G}$ for the first position of the codon, $\mathrm{GTR}+\mathrm{I}+\mathrm{G}$ for the second position of the codon and GTR $+\mathrm{G}$ for the third position of the codon. The Bayesian dendrogram was computed with the program MrBayes ver. 3.2.7a (Huelsenbeck \& Ronquist 2001; Ronquist \& Huelsenbeck 2003), as implemented in CIPRES. Two independent runs, each of four Metropoliscoupled Markov chains Monte Carlo method, were launched for $2 \times 10^{7}$ generations, and trees were sampled every 1000 generations. Convergence of runs was assessed by tracking average standard deviation of split frequencies between runs and by plotting the log likelihood of sampled trees in TRACER ver. 1.7 (Rambaut et al. 2018) and the first $2 \times 10^{6}$ sampled generations were discarded as burn-in. In the distance-based ABGD method, the sequences are sorted into hypothetical species based on the barcode gap (i.e., whenever the divergence among organisms belonging to the same species is smaller than divergence among organisms from different species). The method first detects the barcode gap as the first significant gap beyond a model-based one-sided confidence limit for intraspecific divergence, and then uses it to partition the data. ABGD settings for the COI dataset were: prior minimum divergence of intraspecific diversity $(\mathrm{Pmin})=0.001$; prior maximum divergence of intraspecific diversity $(\operatorname{Pmax})=0.1$; Steps $=10$ and gap width $=1.5$. The analysis was performed on the ABGD website (https://bioinfo.mnhn.fr/abi/public/abgd/abgdweb.html).

\author{
Abbreviations \\ DIC $=$ Differential Interference Contrast light Microscopy \\ $\mathrm{LM}=$ Light Microscopy \\ $\mathrm{PhC}=$ Phase Contrast light Microscopy \\ SEM = Scanning Electron Microscopy
}

\title{
Repository
}

UNIMORE = Department of Life Sciences, University of Modena and Reggio Emilia, via G. Campi 213/d, Modena, Italy

\section{Results}

\section{Taxonomic account of the new species}

\author{
Phylum Tardigrada Doyère, 1840 \\ Class Eutardigrada Richters, 1926 \\ Order Parachela Schuster, Nelson, Grigarick \& Christenberry, 1980 \\ Superfamily Macrobiotoidea Thulin, 1928 in Marley et al. 2011 \\ Family Macrobiotidae Thulin, 1928 \\ Genus Macrobiotus C.A.S. Schultze, 1834 \\ Macrobiotus azzunae sp. nov. \\ urn:1sid:zoobank.org:act:933CCC06-F69D-49E2-AF4F-0C042D8F5C99
}

Figs $1-4,5 \mathrm{~A}, \mathrm{C}, 7$

\section{Etymology}

The new species is dedicated in honor of Atf Azzouna, professor in the Faculty of Mathematical, Physical and Natural Sciences of Tunis and supervisor of the PhD thesis of Jamila Ben Marnissi. 


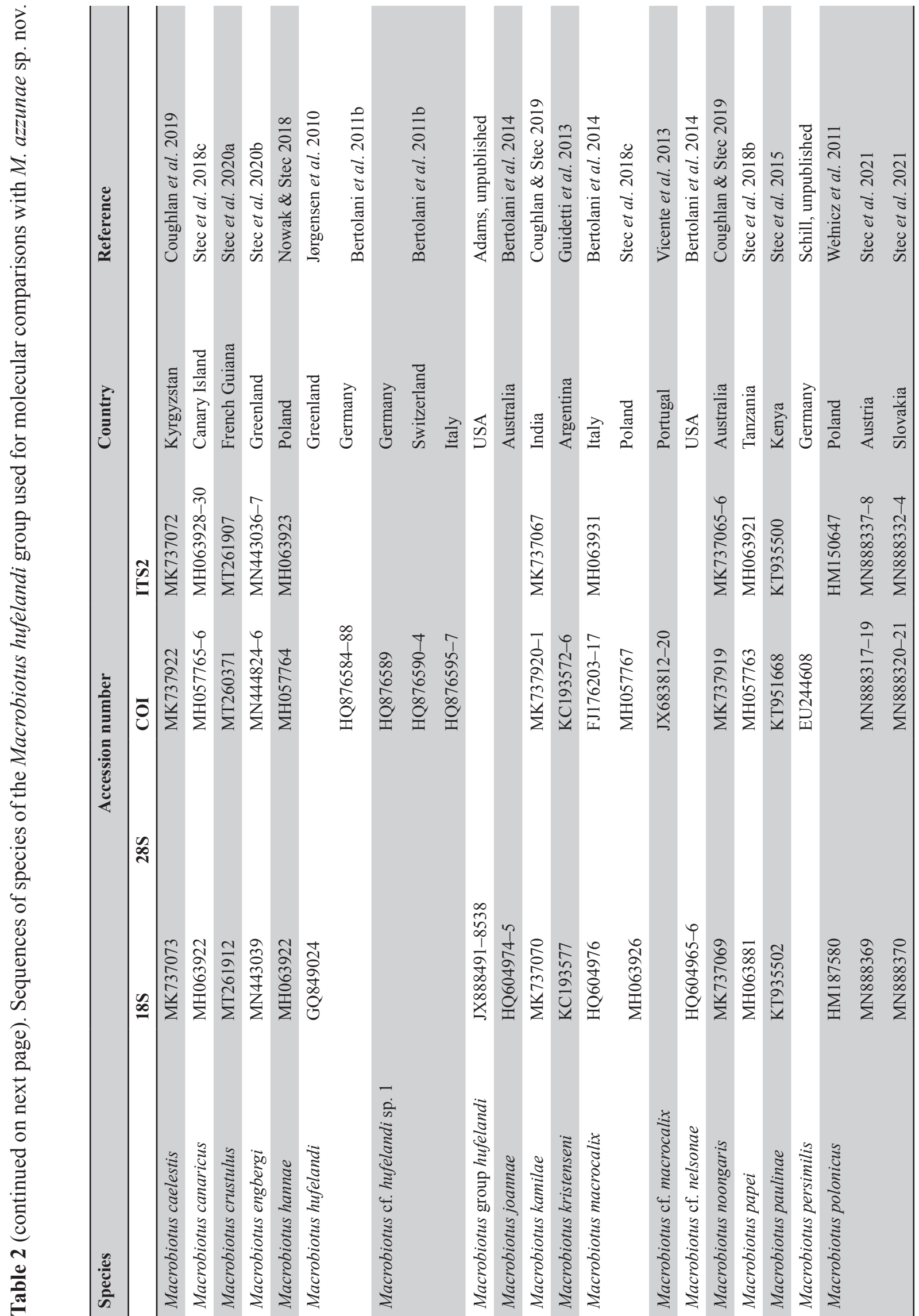




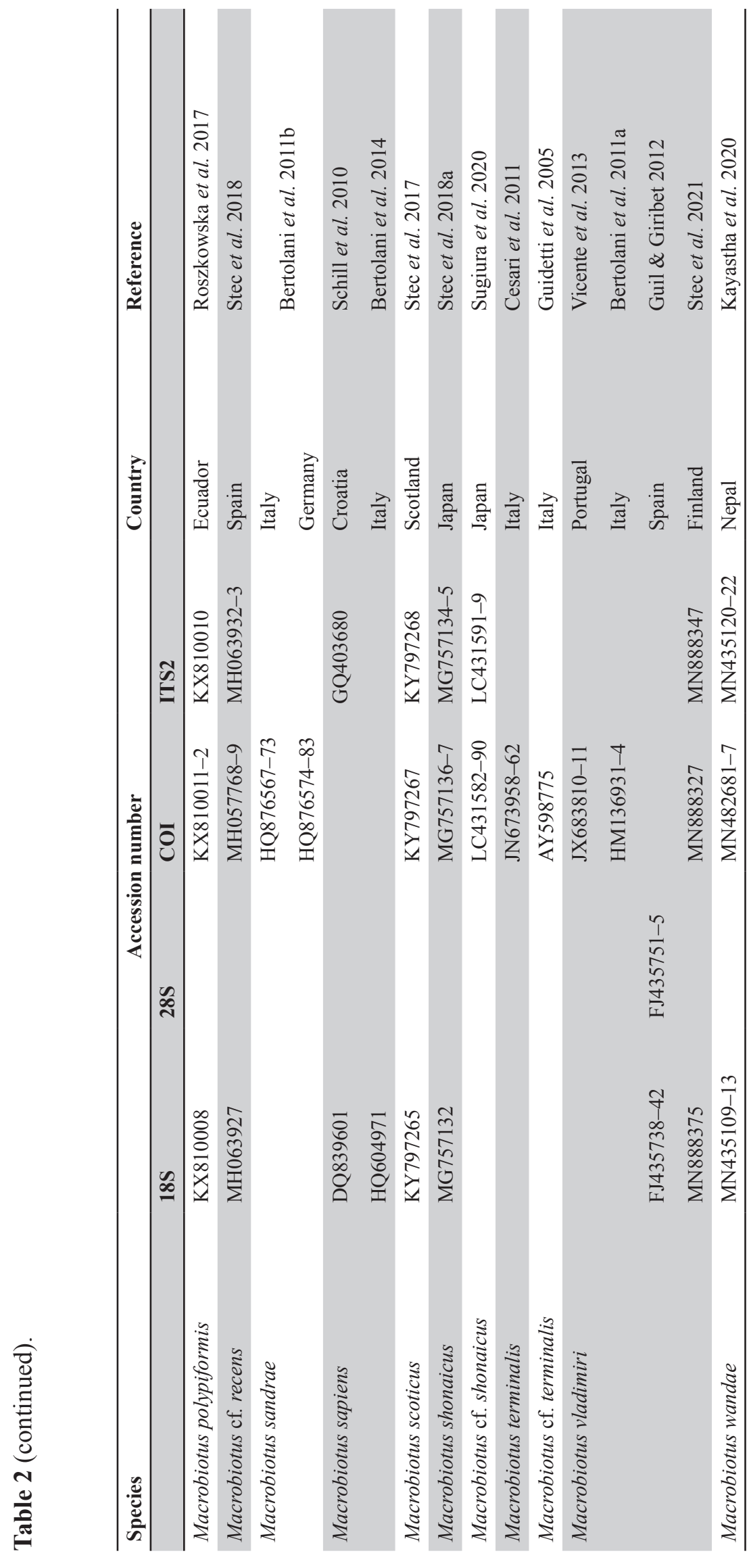




\section{Type material}

\section{Holotype}

TUNISIA - spec. of unidentified sex; North-West Tunisia, Kroumiri Mountains, Ain Soltan forest, Jendouba; 36³1'21.788" N, 8¹9'57.741" E; 893 m a.s.1.; Apr. 2017; Marnissi leg.; moss on trunk of Quercus canariensis; UNIMORE, slide code C4218-S32.

\section{Paratypes}

TUNISIA 17 specs, sex unidentified; same collection data as for holotype; UNIMORE, slide codes C4218-S2 to C4218-S7, C4218-S9, C4218-S17, C4218-S30, C4218-S31, C4218-S33 to C4218S35 - 3 eggs; same collection data as for holotype; UNIMORE, slide codes C4218-S10, C4218-S11, C4218-S25.

\section{Type depositories}

The holotype (slide: C4218-S32), 17 paratypes (slides C4218-S2 to C4218-S7, C4218-S17, C4128S30, C4218-S31, C4218-S33 to C4218-S35), 3 eggs (slides: C4218-S10/11/25) and two vouchers (slides SP04 and SP07, corresponding to specimens C4218 V4 and C4218 V7, respectively) mounted in Faure-Berlese fluid, are deposited in the Bertolani collection at the Department of Life Science, UNIMORE, Modena, Italy.

\section{Type locality}

NW Tunisia, Kroumrie mountains, Ain Soltan forest, Jendouba, 36³1'21.788" N, $8^{\circ} 19^{\prime} 57.741^{\prime \prime}$ E. Altitude 893 m a.s.l.

\section{Description}

\section{Adult specimens}

Body white, transparent after mounting in Faure-Berlese, from 162.2 to $410.3 \mu \mathrm{m}$ in length (Fig. 2A, Table 3; structures measured only in the animals more than $200 \mu \mathrm{m}$ in length). Eye spots present, even after mounting. Cuticle smooth but with small round or oval pores, $1-1.5 \mu \mathrm{m}$ in diameter (Fig. 2B), better visible after fixation in Carnoy and orcein staining (Fig. 3C), scattered randomly on the entire cuticle, including the dorsal surface of all legs. With SEM, pores look oval or in the shape of a seed (Fig. 3A, D) with the largest diameter of $0.7-0.8 \mu \mathrm{m}$. Weak cuticular granulation also present on the lateral surface of all legs and specially on legs IV (Fig. 2B, arrow). Only with SEM is it possible to define the shape of the granulation on the legs, which looks as a regular disposition of star-shaped protuberances (about $0.3 \mu \mathrm{m}$; Fig. 3F). Six buccal sensory lobes around the mouth, well recognizable with SEM. Mouth antero-ventral; buccal-pharyngeal apparatus of the Macrobiotus type (sensu Pilato \& Binda 2010), with ventral lamina and ten small peribuccal lamellae (in the holotype, after mounting, separated from the mouth). Buccal armature, corresponding to oral cavity armature, OCA, according to Michalczyk \& Kaczmarek (2003), without an anterior band of teeth visible, corresponding to the first band of teeth according to Michalczyk \& Kaczmarek (2003), and to the anterior band of the buccal ring according to Guidetti et al. (2012); posterior band of teeth poorly visible, corresponding to second band of teeth, according to Michalczyk \& Kaczmarek (2003), followed by three dorsal and three ventral crests, corresponding to third band of teeth according to Michalczyk \& Kaczmarek (2003); the dorsal crests (Fig. 2D) are distinct transverse ridges, whereas the ventral crests (Fig. 2E) appear as two separate lateral transverse ridges and a roundish median tooth. The posterior band of teeth and the transverse ridges are part of the buccal tube, according to Guidetti et al. (2012). Buccal tube narrow; pharyngeal bulb spherical with triangular apophyses, two rod-shaped macroplacoids, relatively short, the first longer than the second and evidently but not deeply narrowed at its middle (Fig. 2C), the second with a not particularly evident subterminal constriction. Microplacoid present. Slender claws of the hufelandi type (sensu Pilato \& Binda 2010); the external claw longer than the internal one and the posterior longer than 


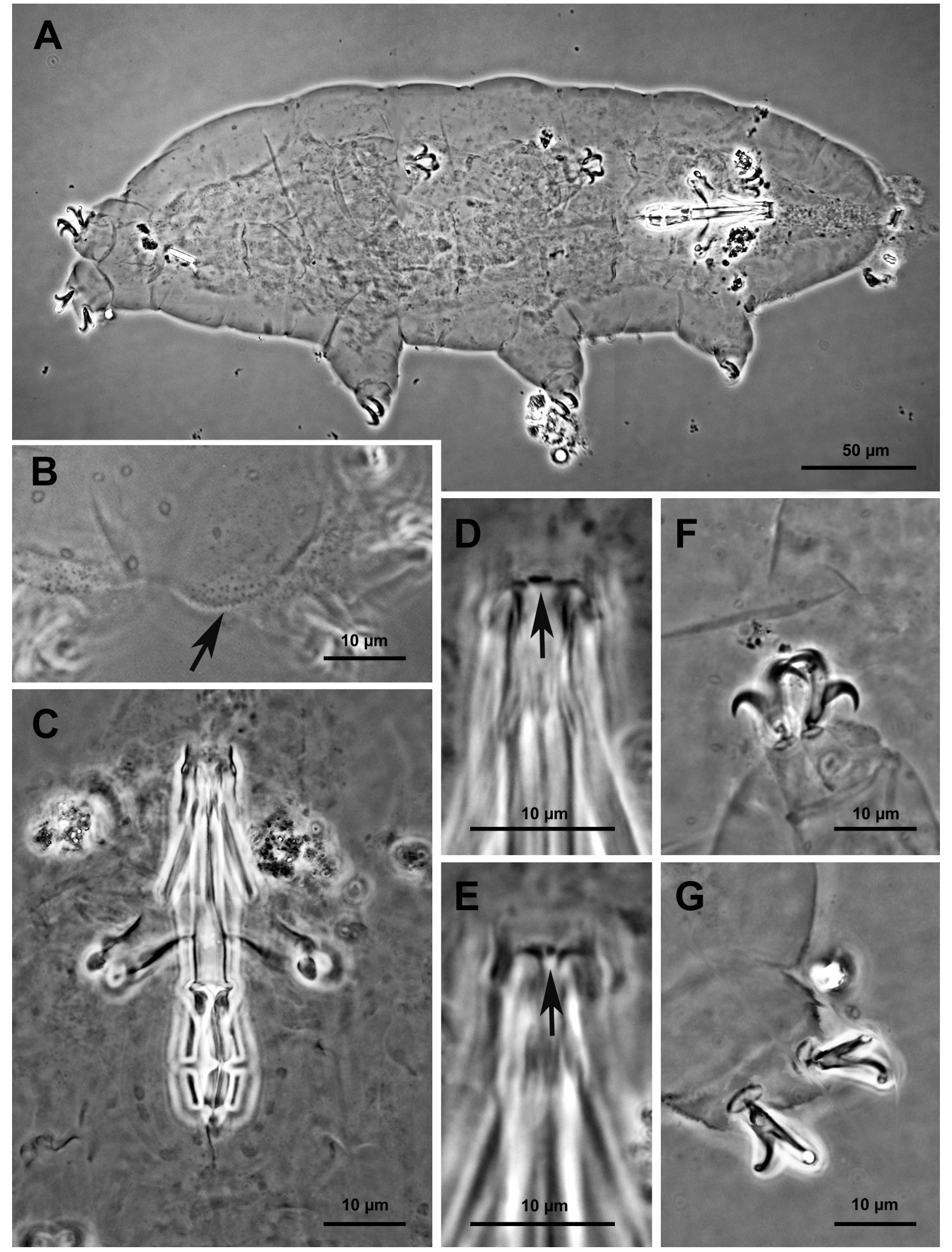

Fig. 2. Macrobiotus azzunae sp. nov., holotype (UNIMORE, slide C4218-S32). A. In toto animal. B. Cuticular pores and leg granulation (arrow) on the hind legs. C. Buccal-pharyngeal apparatus. D. Buccal armature: dorsal crests (arrow). E. Buccal armature: ventral crests (arrow). F. Claw and lunulae of the third pair of legs. G. Claw and lunulae of the fourth pair of legs. A-G: PhC. 

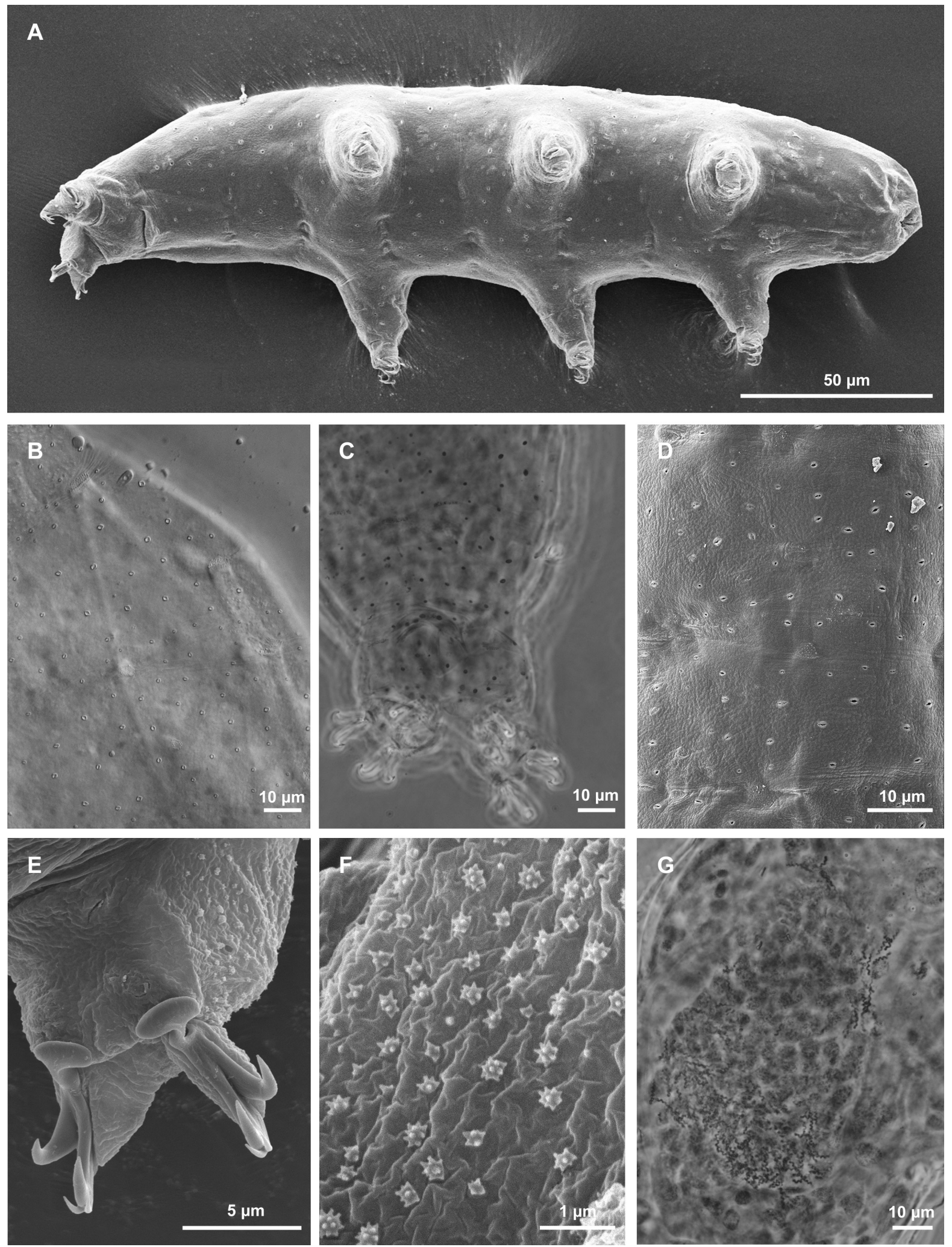

Fig. 3. Macrobiotus azzunae sp. nov., paratypes. A. In toto animal. B-D. Cuticular pores. E. Fourth pair of legs with smooth lunules and peculiar granulation on the legs. F. Granulation on the legs with a starshaped organization. G. Male with testis full of mature spermatozoa with elongate, helicoidal nucleus. A, D-F: SEM (stub-C4218); B: in vivo DIC; C, G: orcein (not permanent slide TN02-04) PhC. 
Table 3. Measurements (in $\mu \mathrm{m}$ ) and $p t$ of selected morphological structures of individuals of Macrobiotus azzunae sp. nov. mounted in Faure-Berlese. Abbreviations: $\mathrm{Nr}=$ number of specimens/structures measured; Range $=$ smallest-largest value; SD = standard deviation. ${ }^{*}$ Three animals below $200 \mu \mathrm{m}$ in length were not considered in the analysis. Two were not measurable, while data of the only measurable animal below $200 \mu \mathrm{m}$ is available in the supplementary material (Supp. file 1).

\begin{tabular}{lcccccc}
\hline \multicolumn{1}{c}{ Character } & $\mathbf{N r}$ & Range $\boldsymbol{\mu m}$ & Mean \pm SD & \multicolumn{2}{c}{ Holotype $\boldsymbol{\mu m}$} \\
\hline Body length & $10^{*}$ & $246.0-410.3$ & & 374.0 & \\
\hline Buccal tube length & 13 & $29.4-38.5$ & & 36.6 & \\
\hline & & & $\boldsymbol{p t}$ & $\boldsymbol{\mu m}$ & $\boldsymbol{p t}$ \\
\hline Buccal tube external width & 13 & $11.6-15.9$ & $13.3 \pm 1.2$ & 5.8 & 15.9 \\
\hline Stylet support insertion point & 13 & $75.1-80.5$ & $76.7 \pm 1.5$ & 27.9 & 76.1 \\
\hline Placoid row & 13 & $50.1-57.7$ & $51.8 \pm 2.4$ & 18.9 & 51.5 \\
\hline Macroplacoid row & 13 & $37.7-48.7$ & $44.6 \pm 3.1$ & 15.7 & 42.7 \\
\hline First macroplacoid & 13 & $24.3-29.7$ & $26.6 \pm 2.2$ & 9.3 & 25.5 \\
\hline Second macroplacoid & 13 & $16.0-20.7$ & $18.3 \pm 1.5$ & 6.6 & 18.1 \\
\hline Microplacoid & 13 & $5.9-8.6$ & $6.9 \pm 1.0$ & 2.6 & 7.0 \\
\hline External Claws III main branch & 13 & $27.1-31.3$ & $29.8 \pm 1.3$ & 11.5 & 31.3 \\
\hline External Claws III secondary branch & 13 & $20.1-25.8$ & $22.5 \pm 1.6$ & 8.1 & 22.1 \\
\hline Internal Claws III main branch & 13 & $24.9-30.2$ & $27.7 \pm 1.6$ & 10.2 & 27.9 \\
\hline Internal Claws III secondary branch & 13 & $18.8-24.2$ & $21.4 \pm 1.7$ & 7.2 & 19.7 \\
\hline Posterior Claws IV main branch & 9 & $29.1-34.6$ & $32.7 \pm 1.8$ & 12.2 & 33.2 \\
\hline Posterior Claws IV secondary branch & 9 & $21.6-24.9$ & $23.8 \pm 1.6$ & 9.1 & 24.9 \\
\hline Anterior Claws IV main branch & 10 & $28.2-32.5$ & $30.1 \pm 1.9$ & 11.1 & 30.3 \\
\hline Anterior Claws IV secondary branch & 10 & $20.4-26.2$ & $23.2 \pm 1.7$ & 8.8 & 24.0 \\
\hline
\end{tabular}

the anterior. Primary branches of each claw with distinct accessory points (Fig. 2F), a common tract of medium length (about a third of the total claw length) and an evident stalk connecting the claw to the lunule. Lunules under all claws, smooth, larger on the hind legs (Figs 2G, 3E). Cuticular bars under claws absent.

The population is dioecious (gonochoristic). Males were recognized using orcein staining, which revealed that the testis is filled with spermatozoa with a coiled head (Fig. 3G) and spermatids. No morphological secondary sexual dimorphism, such as gibbosities on legs IV in males, was identified.

\section{Eggs}

Eggs are laid freely, and are white, spherical or slightly oval. One egg containing a fully developed embryo showed the shape of the buccal-pharyngeal apparatus (Fig. 4A). Processes of the eggshell are in the shape of inverted goblets (Fig. 4B) with conical trunks and well-defined distal discs as large as the process bases (for measurements see Table 4). Distal discs concave, with a median small protuberance and, using PhC, with border often smooth, or sometimes slightly jagged, or slightly ragged (Fig. 4C), 
Table 4. Measurements (in $\mu \mathrm{m}$ ) of selected morphological structures of the eggs of Macrobiotus azzunae sp. nov. mounted in Faure-Berlese. Abbreviations: $\mathrm{Nr}=$ number of eggs/structures measured; Range $=$ smallest-largest value; $\mathrm{SD}=$ standard deviation.

\begin{tabular}{lccc}
\hline Character & Nr & Range & Mean \pm SD \\
\hline Egg diameter without processes & 2 & $64.7-80.6$ & - \\
Egg diameter with processes & 2 & $72.4-89.2$ & - \\
Process nr on egg circumference & 2 & $29-33$ & - \\
Process height & 10 & $4.2-6.4$ & $5.4 \pm 0.6$ \\
Process base width & 10 & $3.2-5.2$ & $4.2 \pm 0.5$ \\
Distal disc width & 10 & $3.2-5.2$ & $4.4 \pm 0.6$ \\
Inter process distance & 10 & $2.7-4.8$ & $3.5 \pm 0.5$ \\
\hline
\end{tabular}
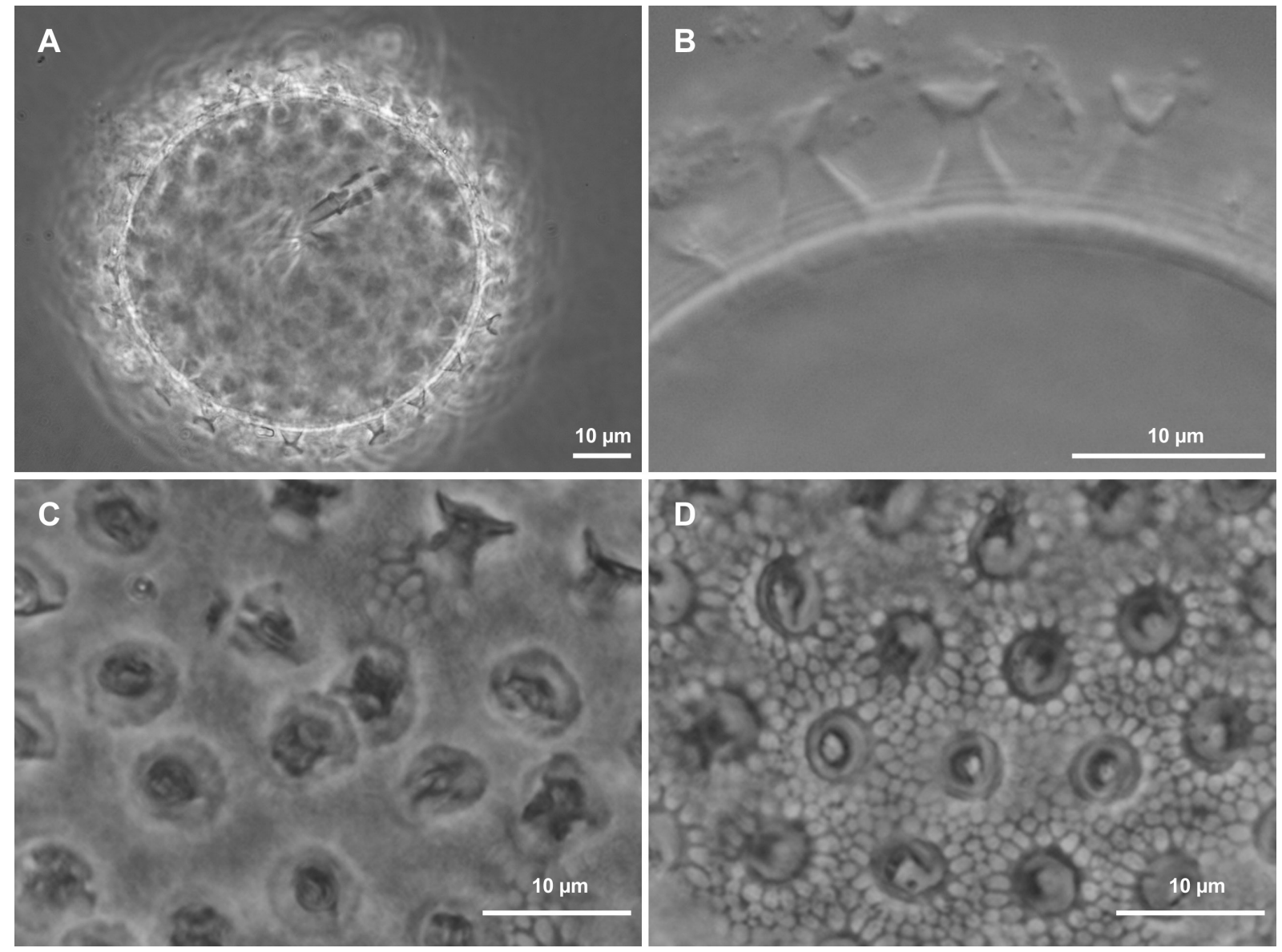

Fig. 4. Egg of Macrobiotus azzunae sp. nov., paratype (UNIMORE, slide C4218-S11). A. In toto egg with buccal-pharyngeal apparatus of its embryo at the end of development. B. Processes of the eggshell (midsection). C. Distal discs of the eggshell processes. D. Surface of the eggshell between processes. A, C-D: PhC; B: DIC. 
but never clearly jagged, serrated or dentate. Surface among processes of the hufelandi type (sensu Kaczmarek \& Michalczyk 2017a), i.e., covered by a very thin grid (Fig. 4D). Meshes around the process bases slightly larger and with slightly thicker wires compared with interbasal meshes. Mesh diameter around $0.5 \mu \mathrm{m}$.

\section{Comparisons}

Macrobiotus azzunae sp. nov. has eggs with processes as inverted goblets and a reticulate eggshell between the processes. Consequently, a comparison must be done with the Macrobiotus species listed by Kaczmarek \& Michalczyk (2017a) with hufelandi type eggshells, excluding the species with processes that are not like inverted goblets, and adding the species with hufelandi type chorion eggs described after that publication. The species with hufelandi type chorion eggs that do not have processes as inverted goblets are Macrobiotus acadianus (Meyer \& Domingue, 2011), M. dariae Pilato \& Bertolani, 2004, M. lissostomus Durante Pasa \& Maucci, 1979, M. santoroi Pilato \& D'Urso, 1976, and M. scoticus Stec, Morek, Gąsiorek, Blagden \& Michalczyk, 2017. Moreover, M. azzunae sp. nov. has egg processes with distal discs with a smooth or slightly jagged border, therefore it differs from all the species that have clearly indented, serrated or clearly jagged distal discs, such as: Macrobiotus canaricus Stec, Krzywański \& Michalczyk, 2018, M. crustulus Stec, Dudziak \& Michalczyk, 2020, M. hannae Nowak \& Stec, 2018 (whose egg surface is more cribriform than reticulate), M. hibiscus de Barros, 1942, M. horningi Kaczmarek \& Michalczyk, 2017b (which also has very high processes), M. hufelandi C.A.S. Schultze, 1834, M. humilis Binda \& Pilato, 2001, M. iharosi Pilato, Binda \& Catanzaro 1991, M. joannae Pilato \& Binda, 1983, M. julianae (Meyer, 2012), M. kamilae Coughlan \& Stec, 2019, M. modestus Pilato \& Lisi, 2009, M. noonragis Coughlan \& Stec, 2019, M. papei Stec, Kristensen \& Michalczyk, 2018 (with particularly long filaments starting from the distal disc), M. paulinae Stec, Smolak, Kaczmarek \& Michalczyk, 2015, M. polypiformis Roszkowska, Ostrowska, Stec, Janko \& Kaczmarek, 2017 (even with cog-teeth extended to form a long, thin, hair-like and flexible filament), M. punctillus Pilato, Binda \& Azzaro, 1990, M. sapiens Binda \& Pilato, 1984, M. sottilei Pilato, Kiosya, Lisi \& Sabella, 2012.

For the shape of the egg Macrobiotus azzunae sp. nov. differs from M. rawsoni Horning, Schuster \& Grigarick, 1978 because this species has only one strip of meshes around each egg process (see Kaczmarek \& Michalczyk 2017b); it differs from M. serratus Bertolani, Guidi \& Rebecchi, 1996 because in this species the egg surface is porous more than reticulated, with pores small and spaced from each other, and its egg processes have a large, often square, distal disc; it differs from $M$. seychellensis Biserov, 1994 because the distal disc of the egg processes of this species, even though not dentate, has long and very developed lobes.

The remaining nine species of the hufelandi group should be compared singularly.

\section{Macrobiotus almadai Fontoura, Pilato \& Lisi, 2008}

Macrobiotus azzunae sp. nov. differs from M. almadai in having a posterior band of teeth in the buccal cavity visible with LM (not visible in M. almadai), and distal disc with a jagged margin instead of very small teeth as in M. almadai.

\section{Macrobiotus canaricus Stec, Krzywański \& Michalczyk, 2018}

With LM the margin of the distal disc of M. azzunae sp. nov., never dentate in this species, looks similar to that of M. canaricus, but the SEM images of the eggs of the latter species evidence the presence of an almost dentate disc. Moreover, the peribasal meshes of the eggshell are larger than interbasal ones in the new species while they do not differ from the interbasal ones in M. canaricus; regarding the animals there are differences in the buccal armature: in M. azzunae sp. nov. the posterior band of teeth is visible with LM (even though poorly) and the three dorsal crests are distinct transverse ridges, while 
in M. canaricus the posterior band of teeth is visible only with SEM and with LM the dorsal teeth form a transversal ridge weakly divided into three teeth.

\section{Macrobiotus madegassus Maucci, 1993}

The new species differs from M. madegassus by the presence of the eye spots (absent in M. madegassus), pores on the cuticle (absent in M. madegassus), presence in the buccal armature of posterior band of teeth, even though weak (fully absent in M. madegassus), buccal tube much larger ( $p t$ of the holotypes 15.9 vs 7), insertion of the stylet supports on the buccal tube much more posterior ( $p t$ of the holotypes 76.1 vs 68), first and second macroplacoid longer ( $p t$ of the holotypes 25.5 and 18.1 vs 21.3 and 12.0), lunules on the hind legs without kerning (crenate in M. madegassus), eggshell processes with distal disc as large as the base (similar range 3.2-5.2 for both measurements) with respect to that of $M$. madegassus (disc vs base: $4.3-5.4$ vs $2.3-2.6$ ).

\section{Macrobiotus martini Bartels, Pilato, Lisi \& Nelson, 2009}

The cuticular pores in M. azzunae sp. nov. are much smaller than those of M. martini; the distal disc of the egg processes in M. azzunae sp. nov. has a diameter similar to that of the process base, while in M. martini the distal disc is much narrower than the base.

\section{Macrobiotus nebrodensis Pilato, Sabella, D'Urso \& Lisi, 2017}

Macrobiotus azzunae sp. nov. differs from M. nebrodensis by the absence of the cuticular bar near the lunules on the first three pairs of legs (a faint bar is present in M. nebrodensis). The egg processes of M. azzuane sp. nov. are in higher number on the circumference (29-33) with respect to those of M. nebrodensis (18). In the latter species there are some egg processes very high (up to $20.6 \mu \mathrm{m}$ ), while in the new species process height and shape are more uniform. The difference in the eggshell between meshes around the process base and the others is much less evident in M. azzunae sp. nov. than in M. nebrodensis.

\section{Macrobiotus personatus Biserov, 1990}

The new species differs from M. personatus by the posterior band of the buccal armature less evident, the presence of a clear constriction in the first macroplacoid (Fig. 5A), in the paratype of M. personatus examined by us barely identifiable (Fig. 6A) and, according to Biserov (1990) usually absent in the type material of that species. The pores on the cuticle of M. azzunae sp. nov. are small, approximately $1 \mu \mathrm{m}$ in diameter, while in M. personatus they are strongly elliptic and about $3 \mu \mathrm{m}$ in length (Fig. 6B). Lunules on leg IV are always smooth in M. azzunae sp. nov., sometimes indented in $M$ personatus. With respect to the eggs of $M$. personatus (Fig. 6C-D), the egg processes of M. azzunae sp. nov. (Figs $4 \mathrm{C}-\mathrm{D}, 5 \mathrm{C}$ ) are clearly shorter, $5.4 \pm 0.6$ vs $9.5 \pm 0.5$ (range 4.2-6.4 vs 9-10.5) and with a narrower base and distal disc (both 3.2-5.2 vs 7-10.5 and 7-9 respectively). Males are present in the new species, while in M. personatus only females were found (Biserov 1990), suggesting parthenogenesis in that species.

\section{Macrobiotus sandrae Bertolani \& Rebecchi, 1993}

The new species differs from M. sandrae for the eggshell shape, with thinner wires of the reticulum and meshes around the processes larger than the inter-process meshes in M. azzunae sp. nov. (Fig. 5C), all meshes similar in size in M. sandrae (Fig. 5D). Figure 5C-D also show a difference in the process base diameter, narrower in M. azzunae sp. nov.With regard to the animals, M. azzunae sp. nov. differs from M. sandrae by a constriction of the first macroplacoid much more pronounced (Fig. 5A; it is hardly visible in M. sandrae; Fig. 5B). Moreover, in animals of similar size the posterior band of the buccal armature is just less evident in the new species, and lunules on the hind legs are without hint of teeth (but teeth, present in the holotype of M. sandrae, are often difficult to identify in other specimens of that species). 


\section{Macrobiotus terminalis Bertolani \& Rebecchi, 1993}

Macrobiotus azzunae sp. nov. differs from M. terminalis for the absence of granulation on the cuticle (noted only in the redescription of M. terminalis; see Cesari et al. 2011), for the absence of teeth on the lunules, especially evident on the hind legs of $M$. terminalis, and for the presence of males, absent in M. terminalis (see redescription by Cesari et al. 2011).
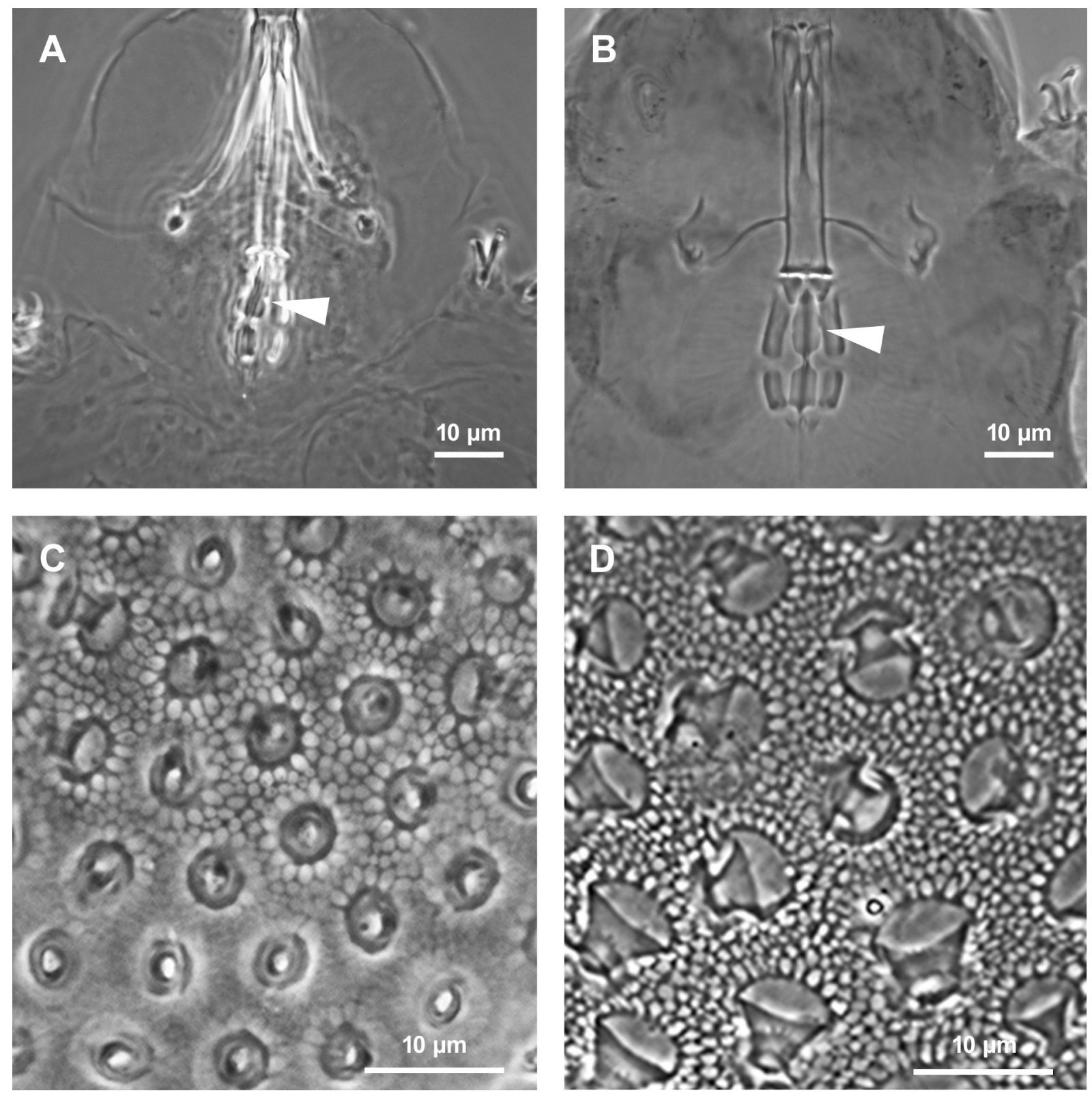

Fig. 5. Comparison between M. azzunae sp. nov. and M. sandrae Bertolani \& Rebecchi, 1993. A. Placoids in M. azzunae sp. nov., paratype (UNIMORE, slide C4218-S30). B. Placoids in M. sandrae (UNIMORE, slide C442-S79); arrowheads evidence the different constriction depth of the first macroplacoid. C. Eggshell in M. azzunae sp. nov., paratype (UNIMORE, slide C4218-S4). D. Eggshell in M. sandrae (UNIMORE, slide C2346-S2); in M. azzunae sp. nov. there are smaller processes and reticulation with thinner wires and larger net around the processes than in M. sandrae. A-D: PhC. 
BEN MARNISSI J. et al., Description of a new Tunisian tardigrade species
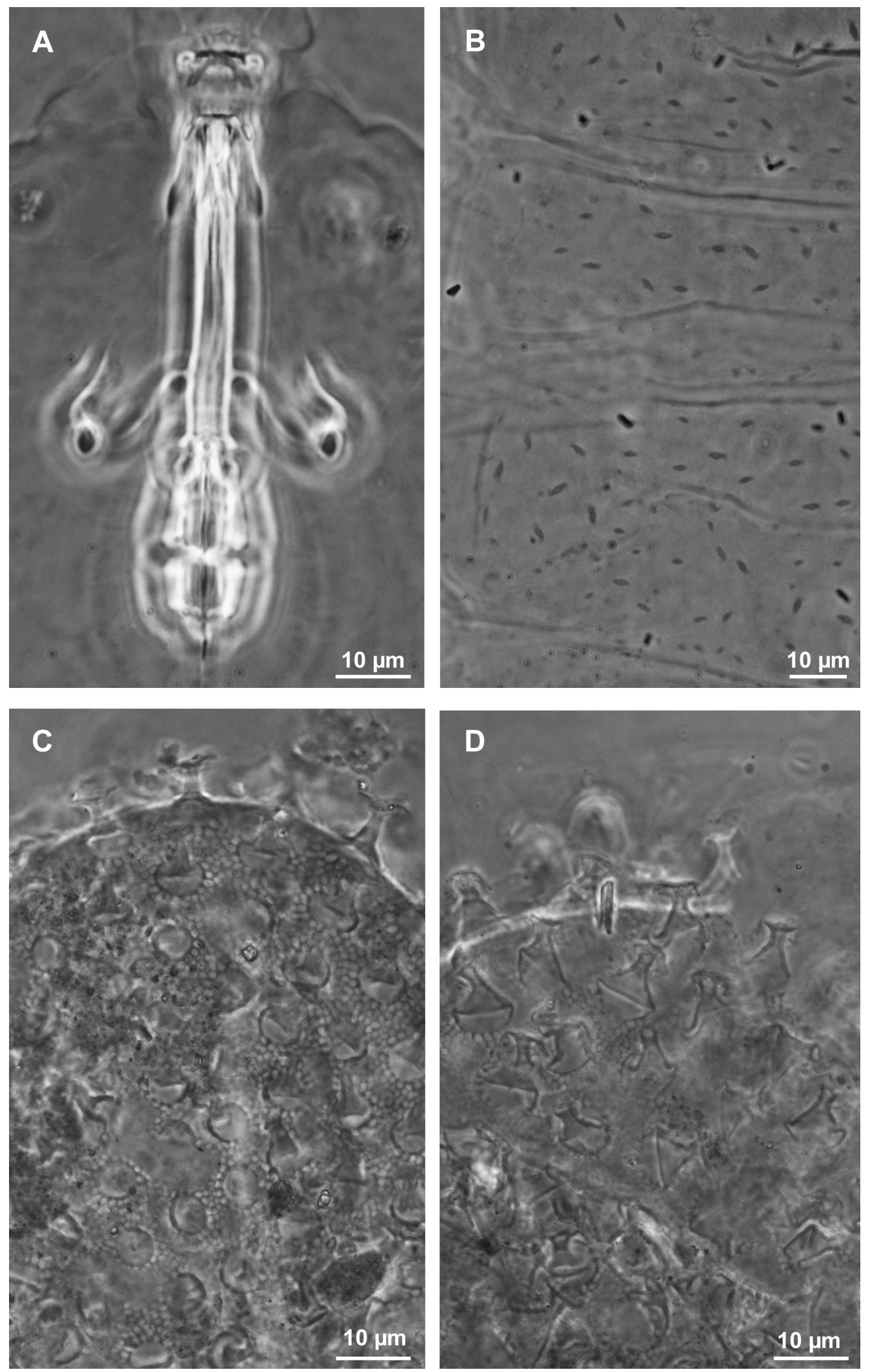

Fig. 6. Macrobiotus personatus Biserov, 1990, paratypes (Civic Museum of Natural History of Verona, Italy, CT14701). A. Buccal-pharyngeal apparatus with macroplacoids. B. Pores on the cuticle. C. Eggshell reticulation and egg processes. D. Egg processes. A-D: PhC. 
Macrobiotus vladimiri Bertolani, Biserov, Rebecchi \& Cesari, 2011

With respect to $M$. vladimiri, animals of M. azzunae sp. nov. reach a shorter length (up to $410.3 \mu \mathrm{m}$ vs $515.1 \mu \mathrm{m}$ ), in M. azzunae sp. nov. the posterior band of teeth of the buccal armature is less evident and the lunules on the hind legs are not indented. In M. azzunae sp. nov. the egg diameter without processes $(64.7-80.6 \mu \mathrm{m})$ is less than that of the eggs of $M$. vladimiri $(89.9-92.0 \mu \mathrm{m})$; the processes are shorter (4.2-6.4 $\mu \mathrm{m}$ in the new species vs $6.5-8 \mu \mathrm{m}$ in $M$. vladimiri). In the new species the base process diameter is narrower $(3.2-5.2 \mu \mathrm{m})$ than in $M$. vladimiri $(5.1-7.3 \mu \mathrm{m})$, the distal disc is weakly or not jagged (clearly jagged in $M$. terminalis). In M. azzunae sp. nov. males are present, while they are absent in M. vladimiri.

\section{Genetic distances}

The ranges of uncorrected genetic p-distances between M. azzunae sp. nov. and the other species of the M. hufelandi group (Supp. file 7, Supp. file 8, Supp. file 9, Supp. file 10), are as follows:

$18 \mathrm{~S} \quad 0.1-5.6 \%$, with the most similar being $M$. sandrae from Germany (present paper)

$28 \mathrm{~S} \quad 0.1 \%$, with the only available $M$. vladimiri from Spain (FJ435751-5)

ITS-2 7.7-32.2\%, with the most similar being Macrobiotus vladimiri (MN888347) from Finland

COI 6.3-25.6\%, with the most similar being Macrobiotus sandrae (HQ876574, HQ876577, HQ876578, HQ876579, HQ876581) from Germany

The COI dataset is the most complete and informative for species delimitation investigation. Both phylogenetic reconstructions on the COI dataset resulted in the same topology, and thus the ML tree was utilized for the PTP analysis (Fig. 7, left), which shows 14 putative species clusters: M. crustulus, M. hannae, M. cf.recens, M. canaricus, M. hufelandi, M. cf. hufelandi sp.1, M. terminalis, M. cf. terminalis, M. wandae, M. macrocalix, M. cf. macrocalix, M. vladimiri, M. sandrae and M. azzunae sp. nov. This subdivision is further validated by both the ABGD and the haplotype network analysis (Fig. 7, centre and right). Present molecular data therefore confirms the validity of the erection of M. azzunae sp. nov.

\section{Discussion}

With the discovery of M. azzunae sp. nov. the species identified in Tunisia now comes to 33, all nonmarine. This number is much lower than the number of non-marine species, 120, found in nearby Sicily (Pilato et al. 2017, 2019), an island extensively studied from a tardigradological point of view. This means that there is considerable potential for further discoveries that could come from the study of the various habitats colonized by tardigrades in Tunisia. Furthermore, the results will undoubtedly be greater and more informative if the research is carried out with an integrated approach, as done in this work.

\section{Acknowledgments}

This study was conducted within the framework of collaboration between Jamila Ben Marnissi who obtained personal financial assistance for the travel costs awarded by Prof. Monia Trabelsi (Department of Biological Sciences, Faculty of Mathematical, Physical and Natural Sciences of Tunis, University of Tunis El Manar), the director of the Laboratory of Ecology, Biology and Physiology of aquatic organisms, University of Tunis El Manar of Tunis, and Prof. Lorena Rebecchi, head of the research team of the laboratory of Evolutionary Zoology (EvoZoo, Department of Life Sciences of the University of Modena and Reggio Emilia, Italy), who supported all the investigations from an economical point of view. We would like to thank Paul Bartels (Warren Wilson College, Asheville, NC) for suggestions and English revision of the manuscript and Prof. Roberto Guidetti ADD: (Department of Life Sciences of the University of Modena and Reggio Emilia, Italy) for his collaboration and support. 


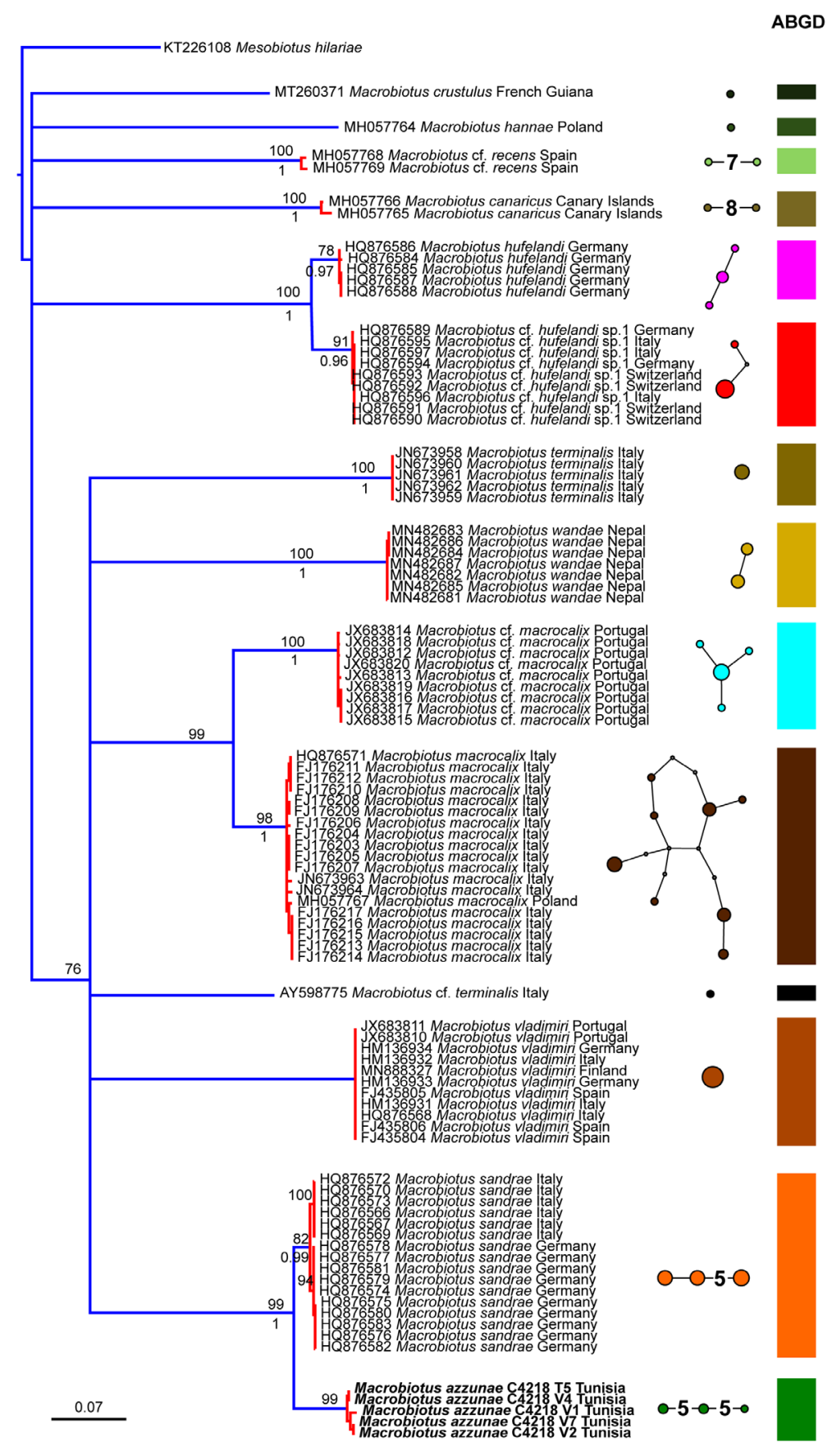

Fig. 7. Left: tree resulting from both the maximum likelihood analysis and the Bayesian inference of cytochrome c oxidase subunit I (COI) in M. azzunae sp. nov. specimens and sequences from GenBank. Values above branches point out bootstrap values, while values under branches represent posterior probability values. Results of the Poisson tree process analysis are provided using differently coloured branches: putative species are indicated using transitions from blue-coloured branches to red-coloured branches. Newly scored haplotypes are in bold. The scale bar shows the number of substitutions per nucleotide position. Centre: haplotype network of COI gene in $M$. hufelandi complex. Circles represent haplotypes, while circle surface denotes haplotype frequency. Networks falling below the value of the 95\% connection limit are disconnected. Right: rectangles denote specimens grouped by ABGD analysis. 


\section{Contribution statement}

The authors contributed equally to this work.

\section{References}

Bertolani R., Biserov V., Rebecchi L. \& Cesari M. 2011a. Taxonomy and biogeography of tardigrades using an integrated approach: new results on species of the Macrobiotus hufelandi group. Invertebrate Zoology 8 (1): 23-26. https://doi.org/10.15298/invertzool.08.1.05

Bertolani R., Rebecchi L., Giovannini I. \& Cesari M. 2011b. DNA barcoding and integrative taxonomy of Macrobiotus hufelandi C.A.S. Schultze 1834, the first tardigrade species to be described, and some related species. Zootaxa 2997: 19-36. https://doi.org/10.11646/zootaxa.2997.1.2

Bertolani R., Guidetti R., Marchioro T., Altiero T., Rebecchi L. \& Cesari M. 2014. Phylogeny of Eutardigrada: new molecular data and their morphological support lead to the identification of new evolutionary lineages. Molecular Phylogenetics and Evolution 76: 110-126.

https://doi.org/10.1016/j.ympev.2014.03.006

Binda M.G. \& Pilato G. 1987. Tardigradi dell'Africa. V: Notizie sui Tardigradi del Nordafrica e descrizione della nuova specie Macrobiotus diffusus. Animalia 14: 177-191.

Biserov V.I. 1990. On the revision of the Macrobiotus genus. The subgenus Macrobiotus s. str. is a new taxonomic status of the hufelandi group (Tardigrada, Macrobiotidae). Communication 2. Zoologicheskij Zhurnal 69: 38-50. [In Russian.]

Cesari M., Bertolani R., Rebecchi L. \& Guidetti R. 2009. DNA barcoding in Tardigrada: the first case study on Macrobiotus macrocalix Bertolani \& Rebecchi, 1993 (Eutardigrada, Macrobiotidae). Molecular Ecology Resources 9 (3): 699-706. https://doi.org/10.1111/j.1755-0998.2009.02538.x

Cesari M., Giovannini I., Bertolani R. \& Rebecchi L. 2011. An example of problems associated with DNA barcoding in tardigrades: a novel method for obtaining voucher specimens. Zootaxa 3104: 42-51. https://doi.org/10.11646/zootaxa.3104.1.3

Cesari M., Vecchi M., Palmer A., Bertolani R., Pilato G., Rebecchi L. \& Guidetti R. 2016. What if the claws are reduced? Morphological and molecular phylogenetic relationships of the genus Haplomacrobiotus May. 1948 (Eutardigrada, Parachela). Zoological Journal of the Linnean Society 178 (4): 819-827. https://doi.org/10.1111/zoj.12424

Cesari M., Montanari M., Kristensen R.M., Bertolani R., Guidetti R. \& Rebecchi L. 2020. An integrated study of the biodiversity within the Pseudechiniscus suillus-facettalis group (Heterotardigrada: Echiniscidae). Zoological Journal of the Linnean Society 188 (3): 717-732.

https://doi.org/10.1093/zoolinnean/zlz045

Clement M., Posada D. \& Crandall K. 2000. TCS: a computer program to estimate gene genealogies. Molecular Ecology 9: 1657-1660. https://doi.org/10.1046/j.1365-294x.2000.01020.x

Coughlan K. \& Stec D. 2019. Two new species of the Macrobiotus hufelandi complex (Tardigrada: Eutardigrada: Macrobiotidae) from Australia and India, with notes on their phylogenetic position. European Journal of Taxonomy 573: 1-38. https://doi.org/10.5852/ejt.2019.573

Coughlan K., Michalczyk Ł. \& Stec D. 2019. Macrobiotus caelestis sp. nov., a new tardigrade species (Macrobiotidae: hufelandi group) from the Tien Shan Mountains (Kyrgyzstan). Annales Zoologici 69 (3): 499-513. https://doi.org/10.3161/00034541ANZ2019.69.3.002

Darriba D., Taboada G.L., Doallo R. \& Posada D. 2012. jModelTest 2: more models, new heuristics and parallel computing. Nature Methods 9 (8): 772. https://doi.org/10.1038/nmeth.2109 
Degma P., Bertolani R. \& Guidetti R. 2020. Actual checklist of Tardigrada. 36 $6^{\text {th }}$ Edition: 8-07-2020. Available from https://iris.unimore.it/retrieve/handle/11380/1178608/227296/ [accessed 28 Jun. 2021].

Gąsiorek P., Stec D., Morek W., Marnissi J. \& Michalczyk Ł. 2017. The tardigrade fauna of Tunisia, with an integrative description of Bryodelphax maculatus sp. nov. (Heterotardigrada: Echiniscidae). African Zoology 52 (2): 77-89. https://doi.org/10.1080/15627020.2017.1297688

Guidetti R. \& Bertolani R. 2005. Tardigrade taxonomy: an updated checklist of the taxa and a list of characters for their identification. Zootaxa 845 (1): 1-46. https://doi.org/10.11646/zootaxa.845.1.1

Guidetti R., Gandolfi A., Rossi V. \& Bertolani R. 2005. Phylogenetic analysis of Macrobiotidae (Eutardigrada,Parachela): a combined morphological and molecular approach. Zoologica Scripta 34: 235-244. https://doi.org/10.1111/j.1463-6409.2005.00193.x

Guidetti R., Altiero T., Marchioro T., Sarzi Amadè L., Avdonina A.M., Bertolani R. \& Rebecchi L. 2012. Form and function of the feeding apparatus in Eutardigrada (Tardigrada). Zoomorphology 131: 127-148. https://doi.org/10.1007/s00435-012-0149-0

Guidetti R., Peluffo J.R., Rocha A.M., Cesari M. \& Moly de Peluffo M.C. 2013. The morphological and molecular analyses of a new South American urban tardigrade offer new insights on the biological meaning of the Macrobiotus hufelandi group of species (Tardigrada: Macrobiotidae). Journal of Natural History 47: 2409-2426. https://doi.org/10.1080/00222933.2013.800610

Guil N. \& Giribet G. 2012. A comprehensive molecular phylogeny of tardigrades — adding genes and taxa to a poorly resolved phylum-level phylogeny. Cladistics 27: 1-29.

https://doi.org/10.1111/j.1096-0031.2011.00364.x

Guindon S. \& Gascuel O. 2003. A simple, fast and accurate method to estimate large phylogenies by maximum-likelihood. Systematic Biology 52: 696-704. https://doi.org/10.1080/10635150390235520

Hart M.W. \& Sunday J. 2007. Things fall apart: biological species form unconnected parsimony networks. Biology Letters 3: 509-512. https://doi.org/10.1098/rsbl.2007.0307

Huelsenbeck J.P. \& Ronquist F. 2001. MRBAYES: Bayesian inference of phylogenetic trees. Bioinformatics 17: 754-755. https://doi.org/10.1093/bioinformatics/17.8.754

Iharos G. 1978. Data to the knowledge of the Tardigrada fauna of Tunisia. Folia Entomologica Hungarica 31: 161-164.

Jørgensen A., Faurby S., Hansen J.G., Møbjerg N. \& Kristensen R.M. 2010. Molecular phylogeny of Arthrotardigrada (Tardigrada). Molecular Phylogenetics and Evolution 54: 1006-1015.

https://doi.org/10.1016/j.ympev.2009.10.006

Kaczmarek Ł. \& Michalczyk Ł. 2017a. The Macrobiotus hufelandi (Tardigrada) group revisited. Zootaxa 4363: 101-123. https://doi.org/10.11646/zootaxa.4363.1.4

Kaczmarek Ł. \& Michalczyk Ł. 2017b. A description of Macrobiotus horningi sp. nov. and redescriptions of M. maculatus comb. nov. Iharos, 1973 and M. rawsoni Horning et al., 1978 (Tardigrada: Eutardigrada: Macrobiotidae: hufelandi group). Zootaxa 4363: 79-100. https://doi.org/10.11646/zootaxa.4363.1.3

Katoh K., Misawa K., Kuma K.I. \& Miyata T. 2002. MAFFT: a novel method for rapid multiple sequence alignment based on fast Fourier transform. Nucleic Acids Research 30: 3059-3066.

https://doi.org/10.1093/nar/gkf436

Katoh K., Rozewicki J. \& Yamada K.D. 2017. MAFFT online service: multiple sequence alignment, interactive sequence choice and visualization. Briefings in Bioinformatics 20 (4): 1160-1166.

https://doi.org/10.1093/bib/bbx108 
Kayastha P., Berdi D., Mioduchowska M., Gawlak M., Łukasiewicz A., Gołdyn B. \& Kaczmarek Ł. 2020. Some tardigrades from Nepal (Asia) with integrative description of Macrobiotus wandae sp. nov. (Macrobiotidae: hufelandi group). Annales Zoologici 70 (1): 121-142. https://doi.org/10.3161/00034541ANZ2020.70.1.007

Kumar A., Sharma P., Gomar Alba M., Shcheprova Z., Daulny A., Sanmartín T., Matucci I., Funaya C., Beato M. \& Mendoza M. 2018. Daughter-cell-specific modulation of nuclear pore complexes controls cell cycle entry during asymmetric division. Nature Cell Biology 20 (4):432-442.

https://doi.org/10.1038/s41556-018-0056-9

McInnes S.J. 1994. Zoogeographic distribution of terrestrial/freshwater tardigrades from current literature. Journal of the Natural History 28: 257-352. https://doi.org/10.1080/00222939400770131

McInnes S.J., Michalczyk Ł. \& Kaczmarek Ł. 2017. Annotated zoogeography of non-marine Tardigrada. Part IV: Africa. Zootaxa 4284: 1-71. https://doi.org/10.11646/zootaxa.4284.1.1

Michalczyk Ł. \& Kaczmarek Ł. 2003. A description of the new tardigrade Macrobiotus reinhardti (Eutardigrada, Macrobiotidae, harmsworthi group) with some remarks on the oral cavity armature within the genus Macrobiotus Schultze. Zootaxa 331: 1-24. https://doi.org/10.11646/zootaxa.331.1.1

Miller M.A., Pfeiffer W. \& Schwartz T. 2010. Creating the CIPRES Science Gateway for inference of large phylogenetic trees. 2010 Gateway Computing Environments Workshop (GCE): 1-8. https://doi.org/10.1109/GCE.2010.5676129

Múrias dos Santos A., Cabezas M.P., Tavares A.I., Xavier R. \& Branco M. 2016. tcsBU: a tool to extend TCS network layout and visualization. Bioinformatics 32 (4): 627-628.

https://doi.org/10.1093/bioinformatics/btv636

Nelson D.R., Guidetti R. \& Rebecchi L. 2015. Phylum Tardigrada. In: Thorp J. \& Rogers D.C. (eds) Ecology and General Biology: Thorp and Covich's Freshwater Invertebrates: 347-380. Academic Press, London. https://doi.org/10.1016/B978-0-12-385026-3.00017-6

Nowak B. \& Stec D. 2018 An integrative description of Macrobiotus hannae sp. nov. (Tardigrada: Eutardigrada: Macrobiotidae: hufelandi group) from Poland. Turkish Journal of Zoology 42: 269-286. https://doi.org/10.3906/zoo-1712-31

Nylander J.A.A. 2004. MrModeltest v2. Program distributed by the author. Evolutionary Biology Centre, Uppsala University.

Pilato G. 1981. Analisi di nuovi caratteri nello studio degli Eutardigradi. Animalia 8: 51-57.

Pilato G. \& Binda M.G. 2010. Definition of families, subfamilies, genera and subgenera of the Eutardigrada, and keys to their identification. Zootaxa 2404: 1-54. https://doi.org/10.11646/zootaxa.2404.1.1

Pilato G. \& Lisi O. 2009. Tardigrades of the Seychelles Islands, with the description of three new species. Zootaxa 2124: 1-20. https://doi.org/10.5281/zenodo.188178

Pilato G., Binda M.G. \& Azzaro M. 1990. Tardigradi di Terra del Fuoco e Magallanes. III. Macrobiotus punctillus, nuova specie di Macrobiotidae del gruppo hufelandi. Animalia 17: 123-129.

Pilato G., Binda M.G. \& Catanzaro R. 1991. Remarks on some tardigrades of the African fauna with the description of three new species of Macrobiotus Schultze 1834. Tropical Zoology 4: 167-178. https://doi.org/10.1080/03946975.1991.10539487

Pilato G., Kiosya Ye., Lisi O. \& Sabella G. 2012. New records of Eutardigrada from Belarus with the description of three new species. Zootaxa 3179: 39-60. https://doi.org/10.11646/zootaxa.3179.1.2 
Pilato G., Sabella G., D’Urso V. \& Lisi O. 2017. Macrobiotus nebrodensis and Adropion vexatum, two new species of Eutardigrada (Tardigrada, Parachela) from Sicily. Zootaxa 4362 (2): 267-279. https://doi.org/10.11646/zootaxa.4362.2.6

Pilato G., D’Urso V., Sabella G. \& Lisi O. 2019. A new species of isohypsibiid (Eutardigrada) from Sicily. Zootaxa 4608 (3): 543-554. https://doi.org/10.11646/zootaxa.4608.3.8

Puillandre N., Lambert A., Brouillet S. \& Achaz G. 2012. ABGD, Automatic Barcode Gap Discovery for primary species delimitation. Molecular Ecology 21: 1864-1877.

https://doi.org/10.1111/j.1365-294X.2011.05239.x

Ramazzotti G. \& Maucci W. 1983. Il Phylum Tardigrada. Memorie dell'Istituto Italiano di Idrobiologia, Pallanza 41: 1-1012.

Rambaut A., Drummond A.J., Xie D., Baele G. \& Suchard M.A. 2018. Posterior summarisation in Bayesian phylogenetics using Tracer 1.7. Systematic Biology 67 (5): 901-904.

https://doi.org/10.1093/sysbio/syy032

Rebecchi L. \& Bertolani R. 1988. New cases of parthenogenesis and polyploidy in the genus Ramazzottius (Tardigrada, Hypsibiidae) and a hypothesis concerning their origin. International Journal of Invertebrate Reproduction and Development 14: 187-196. https://doi.org/10.1080/01688170.1988.10510377

Richters F. 1926. Tardigrada. In: Kukenthal W. \& Krumbach T. (eds) Handbuch der Zoologie, Vol. III: 58-61. Walter de Gruyter \& Co, Berlin and Leipzig.

Ronquist F. \& Huelsenbeck J.P. 2003. MRBAYES 3: Bayesian phylogenetic inference under mixed models. Bioinformatics 19: 1572-1574. https://doi.org/10.1093/bioinformatics/btg180

Roszkowska M., Ostrowska M., Stec D., Janko K. \& Kaczmarek Ł. 2017. Macrobiotus polypiformis sp. nov., a new tardigrade (Macrobiotidae; hufelandi group) from the Ecuadorian Pacific coast, with remarks on the claw abnormalities in eutardigrades. European Journal of Taxonomy 327: 1-19.

https://doi.org/10.5852/ejt.2017.327

Schill R.O. (ed.) 2018. Water Bears: The Biology of Tardigrades. Vol. 419. Springer, Cham, Switzerland.

Schill R.O., Förster F., Dandekar T. \& Wolf M. 2010. Using compensatory base change analysis of internal transcribed spacer 2 secondary structures to identify three new species in Paramacrobiotus (Tardigrada). Organisms Diversity and Evolution 10: 287-296. https://doi.org/10.1007/s13127-010-0025-z

Schultze C.A.S. 1834. Macrobiotus Hufelandii animal e crustaceorum classe novum, reviviscendi post diuturnam asphyxia et ariditaten potens, etc. C. Curths, Berlin.

Schuster R.O, Nelson D.R., Grigarick A.A. \& Christenberry D. 1980. Systematic criteria of the Eutardigrada. Transaction of the American Microscopical Society 99: 284-303. https://doi.org/10.2307/3226004

Stamatakis A. 2006. RAxML-VI-HPC: maximum likelihood-based phylogenetic analyses with thousands of taxa and mixed models. Bioinformatics 22: 2688-2690.

https://doi.org/10.1093/bioinformatics/bt1446

Stamatakis A., Hoover P. \& Rougemont J. 2008. A rapid bootstrap algorithm for the RAxML web servers. Systematic Biology 57: 758-771. https://doi.org/10.1080/10635150802429642

Stambouli-Essassi S., Roche E. \& Bouzid S. 2007. Evolution of vegetation and climatic changes in North-Western Tunisia during the last 40 millennia. Geo-Eco-Trop 31: 171-214.

Stec D., Smolak R., Kaczmarek Ł. \& Michalczyk Ł. 2015. An integrative description of Macrobiotus paulinae sp. nov. (Tardigrada: Eutardigrada: Macrobiotidae: hufelandi group) from Kenya. Zootaxa 4052 (2): 501-526. https://doi.org/10.11646/zootaxa.4052.5.1 
Stec D., Morek W., Gąsiorek P., Blagden B. \& Michalczyk Ł. 2017. Description of Macrobiotus scoticus sp. nov. (Tardigrada: Macrobiotidae: hufelandi Group) from Scotland by means of integrative taxonomy. Annales Zoologici 67 (2): 181-197. https://doi.org/10.3161/00034541ANZ2017.67.2.001

Stec D., Arakawa K. \& Michalczyk Ł. 2018a. An integrative description of Macrobiotus shonaicus sp. nov. (Tardigrada: Macrobiotidae) from Japan with notes on its phylogenetic position within the hufelandi group. PLoS ONE 13 (2): e0192210. https://doi.org/10.1371/journal.pone.0192210

Stec D., Kristensen R.M. \& Michalczyk L. 2018b. Integrative taxonomy identifies Macrobiotus papei, a new tardigrade species of the Macrobiotus hufelandi complex (Eutardigrada: Macrobiotidae) from the Udzungwa Mountains National Park (Tanzania). Zootaxa 4446 (2): 273-291.

https://doi.org/10.11646/zootaxa.4446.2.7

Stec D., Krzywański Ł. \& Michalczyk Ł. 2018c. Integrative description of Macrobiotus canaricus sp. nov. with notes on M. recens (Eutardigrada: Macrobiotidae). European Journal of Taxonomy 452: 1-36. https://doi.org/10.5852/ejt.2018.452

Stec D., Morek W., Gąsiorek P. \& Michalczyk Ł. 2018d. Unmasking hidden species diversity within the Ramazzottius oberhaeuseri complex, with an integrative redescription of the nominal species for the family Ramazzottiidae (Tardigrada: Eutardigrada: Parachela). Systematics and Biodiversity 16 (4): 357-376. https://doi.org/10.1080/14772000.2018.1424267

Stec D., Dudziak M. \& Michalczyk Ł. 2020a. Integrative descriptions of two new Macrobiotidae species (Tardigrada: Eutardigrada: Macrobiotoidea) from French Guiana and Malaysian Borneo. Zoological Studies 59 (23):1-25. https://doi.org/10.6620/ZS.2020.59-23

Stec D., Tumanov D.V. \& Kristensen R.M. 2020b. Integrative taxonomy identifies two new tardigrade species (Eutardigrada: Macrobiotidae) from Greenland. European Journal of Taxonomy 614: 1-40. https://doi.org/10.5852/ejt.2020.614

Stec D., Vecchi M., Calhim S. \& Michalczyk Ł. 2021. New multilocus phylogeny reorganises the family Macrobiotidae (Eutardigrada) and unveils complex morphological evolution of the Macrobiotus hufelandi group. Molecular Phylogenetics and Evolution 160. https://doi.org/10.1016/j.ympev.2020.106987.

Sugiura K., Arakawa K. \& Matsumoto M. 2020. Distribution of Macrobiotus shonaicus Stec, Arakawa \& Michalczyk, 2018 (Tardigrada: Eutardigrada: Macrobiotidae) in Japan. Zootaxa 4767 (1): 56-70. https://doi.org/10.11646/zootaxa.4778.3.11

Tang C.Q., Humphreys A.M., Fontaneto D. \& Barraclough T.G. 2014. Effects of phylogenetic reconstruction method of the robustness of species delimitation using single-locus data. Methods in Ecology and Evolution 5: 1086-1094. https://doi.org/10.1111/2041-210X.12246

Templeton A.R., Crandall K.A. \& Sing C.F. 1992. A cladistic analysis of phenotypic association with haplotypes inferred from restriction endonuclease mapping and DNA sequence data. III. Cladogram estimation. Genetics 132 (2): 619-633.

Thulin G. 1928. Über die Phylogenie und das System der Tardigraden. Hereditas 11 (2-3): 207-266. https://doi.org/10.1111/j.1601-5223.1928.tb02488.x

Vecchi M., Cesari M., Bertolani R., Jönsson K.I., Rebecchi L. \& Guidetti R. 2016. Integrative systematic studies on tardigrades from Antarctica identify new genera and new species within Macrobiotoidea and Echiniscoidea. Invertebrate Systematics 30: 303-322. https://doi.org/10.1071/IS15033

Vicente F., Cesari M., Serrano A. \& Bertolani R. 2013. The impact of fire on terrestrial tardigrade biodiversity: a first case-study from Portugal. Journal of Limnology 72 (s1): 152-159.

https://doi.org/10.4081/jlimnol.2013.s1.e19 
Wełnicz W., Grohme M.A., Kaczmarek Ł., Schill R.O. \& Frohme L. 2011. ITS-2 and 18S rRNA data from Macrobiotus polonicus and Milnesium tardigradum (Eutardigrada, Tardigrada). Journal of Systematics and Evolutionary Research 49 (s1): 34-39. https://doi.org/10.1111/j.1439-0469.2010.00595.x

Zhang J., Kapli P., Pavlidis P. \& Stamatakis A. 2013. A general species delimitation method with applications to phylogenetic placements. Bioinformatics 29: 2869-2876.

https://doi.org/10.1093/bioinformatics/btt499

Manuscript received: 1 September 2020

Manuscript accepted: 16 April 2021

Published on: 9 July 2021

Topic editor: Rudy Jocqué

Section editor: Daniel Stec

Desk editor: Pepe Fernández

Printed versions of all papers are also deposited in the libraries of the institutes that are members of the EJT consortium: Muséum national d'histoire naturelle, Paris, France; Meise Botanic Garden, Belgium; Royal Museum for Central Africa, Tervuren, Belgium; Royal Belgian Institute of Natural Sciences, Brussels, Belgium; Natural History Museum of Denmark, Copenhagen, Denmark; Naturalis Biodiversity Center, Leiden, the Netherlands; Museo Nacional de Ciencias Naturales-CSIC, Madrid, Spain; Real Jardín Botánico de Madrid CSIC, Spain; Zoological Research Museum Alexander Koenig, Bonn, Germany; National Museum, Prague, Czech Republic.

Supp. file 1. Single measurements (in $\mu \mathrm{m}$ ) and $p t$ values of morphological structures of the holotype and paratypes of Macrobiotus azzunae sp. nov. https://doi.org/10.5852/ejt.2021.758.1429.4625

Supp. file 2. Buccal-pharyngeal apparatus of a hologenophore voucher specimen (C4218 V7) of Macrobiotus azzunae sp. nov. in vivo, PhC. https://doi.org/10.5852/ejt.2021.758.1429.4627

Supp. file 3. Alignment of all Macrobiotus hufelandi group sequences for the $18 \mathrm{~S}$ gene. https://doi.org/10.5852/ejt.2021.758.1429.4629

Supp. file 4. Alignment of all Macrobiotus hufelandi group sequences for the 28S gene. https://doi.org/10.5852/ejt.2021.758.1429.4631

Supp. file 5. Alignment of all Macrobiotus hufelandi group sequences for the ITS-2 gene. https://doi.org/10.5852/ejt.2021.758.1429.4633

Supp. file 6. Alignment of all Macrobiotus hufelandi group sequences for the COI gene. https://doi.org/10.5852/ejt.2021.758.1429.4635

Supp. file 7. Genetic distances (p-distance) computed between species of the Macrobiotus hufelandi group for the 18S gene. https://doi.org/10.5852/ejt.2021.758.1429.4637

Supp. file 8. Genetic distances (p-distance) computed between species of the Macrobiotus hufelandi group for the 28S gene. https://doi.org/10.5852/ejt.2021.758.1429.4639 
Supp. file 9. Genetic distances (p-distance) computed between species of the Macrobiotus hufelandi group for the ITS-2 gene. https://doi.org/10.5852/ejt.2021.758.1429.4641

Supp. file 10. Genetic distances (p-distance) computed between species of the Macrobiotus hufelandi group for the COI gene. https://doi.org/10.5852/ejt.2021.758.1429.4643 